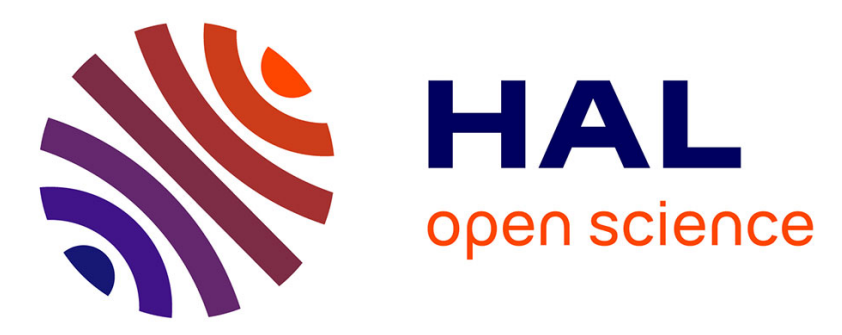

\title{
Ibn Taymiyya on the Proofs of Prophecy and His Legacy: Ibn Qayyim al-Jawziyya (d. 751/1350) and Ibn al-Wazīr (d. 840/1436) \\ Nadjet Zouggar
}

\section{- To cite this version:}

Nadjet Zouggar. Ibn Taymiyya on the Proofs of Prophecy and His Legacy: Ibn Qayyim alJawziyya (d. 751/1350) and Ibn al-Wazìr (d. 840/1436). Muslim World, 2018, 108 (1), pp.172-185. 10.1111/muwo.12233 . hal-02123182

\section{HAL Id: hal-02123182 \\ https://hal.science/hal-02123182}

Submitted on 7 May 2019

HAL is a multi-disciplinary open access archive for the deposit and dissemination of scientific research documents, whether they are published or not. The documents may come from teaching and research institutions in France or abroad, or from public or private research centers.
L'archive ouverte pluridisciplinaire HAL, est destinée au dépôt et à la diffusion de documents scientifiques de niveau recherche, publiés ou non, émanant des établissements d'enseignement et de recherche français ou étrangers, des laboratoires publics ou privés. 


\section{Ibn Taymiyya on the Proofs of Prophecy and His Legacy: \\ Ibn Qayyim al-Jawziyya (d. 751/1350) and Ibn al-Wazīr (d. 840/1436) \\ Nadjet Zouggar}

In Sunni theology, the treatises called nubuwwāt, which is translated as "prophetology," deal with the prophetic institution and tackle a set of classical issues. The proofs of prophecy are usually developed into separate writings called dalä’il alnubuwwa (the proofs of prophecy). ${ }^{1}$ The corpus of the daläil al-nubuwwa can be divided into two categories according to the schools of thought to which the authors of such treatises belong:

a) The treatises of the traditionalists (ahl al-hadith) who rely exclusively on Hadith reporting the prophet Muhammad's miracles. ${ }^{2}$

b) The elaborations of the theologians (al-mutakallimūn) whose works are based also on the reported miracles of the Prophet to which they added speculative arguments, focusing specifically on topics pertaining to his virtues. ${ }^{3}$

The arguments of the treatises vary tremendously according to whether the authors attempt to prove the existence of prophets or whether they try to demonstrate the validity of Muhammad's mission. ${ }^{4}$ The first topic addresses those who refute the very existence of prophecy, while the second addresses those who believe in the

1 Parts of this contribution stem from my doctoral thesis Le prophétisme dans la polémique antiphilosophique en islam Sunnite, unpublished PhD dissertation (Toulouse University, 2008). My PhD dissertation focused on Ibn Taymiyya's writings and brought to light the influence of philosophy on his concept of prophetology.

2 Among these authors are Abū Ja far al-Firyābī (d. 301/913); Abū Nu 'aym al-Iṣfahānī (d. 430/1011) and Abū Bakr al-Bayhaqī (d. 458/1065). All are available in modern editions.

3 Such as the treatises of al-Jāhiz (d. 255/868), al-Māwardī (d. 450/1058), and al-Qāḍ̄ 'Abd alJabbār (d. 415/1025).

4 See S. Stroumsa, Freethinkers of Medieval Islam: Ibn al-Rāwandī, Abū Bakr al-Rāā̄ and Their Impact on Islamic Thought (Leiden: Brill, 1999), 22-27. 
prophetic fact but do not acknowledge Muhammad's mission, namely the Jews and the Christians.

In this article, I will first show how the Hanbalī theologian Taqī al-Dīn Aḥmad ibn Taymiyya (661/1263-728/1328) took part in the discussions relating to the proofs of prophecy. Then, I will expound on the elaborations of the same subject by his followers. Specifically, I will consider Ibn Qayyim al-Jawziyya and Ibn al-Wazīr's writings on prophetology andI will present the transfer of Taymiyyan features in their own methods to prove the existence of prophecy.

Ibn Taymiyya wrote two dissertations on the proofs of prophecy. The first one is in fact the last section of al-Jawāb al-șahịh li-man baddala dīn al-Masīh [The valid response to those who have altered the Messiah's religion], a polemic work written between 1316 and 1321 against Christians and, to a lesser degree, against Jews. ${ }^{5}$ At a first glance, this dissertation seems to concur with the traditionalist genre of the proofs of prophecy (dalä'il al-nubuwwa), as it reports the accounts of the numerous miracles of the prophet Muhammad. Yet, on closer inspection, Ibn Taymiyya's Dalä'il al- nubuwwa comes across as being atypical for its special emphasis on epistemological questions, which traditionalist works on the subject do not usually display. The scope of these questions has to do with establishing that knowledge which is derived from numerous chains of transmitters (al-khabar al-mutawātir, pl. al-mutawātirāt) has the probative value of necessary knowledge.

5 Several critical editions of this major work exist. The most reliable is edited by 'A. b. Hasan alḤamdān, 7 vols (Riyadh: Dār al- 'Āṣima, 1993-94, vols 1-6; 1999, vol. 7, $2^{\text {nd }}$ Printing 1999). For a contextualization and a bibliographical description of this book, see J. Hoover, "Ibn Taymiyya," in Christian-Muslim Relations. A Bibliographical History (1200-1350), eds. David Thomas et al. (Leiden: Brill, 2012), iv: 824-878: 834-844. The last part of al-Jawāb al-ṣahịh was re-edited by H. b. Muhammad al-Hamdān and published in a separate volume under the title Dalä il alnubuwwa by al-'Ubaykān publishers in 2005. It is this edition that is used in this article. 
The second treatise is titled al-Nubuwwät [Prophetology]. Unlike the former, it does not address those who do not believe in Muhammad's mission and is more interested in criticizing the argument of the ancient Ash'arite school in proving prophecy and, to a lesser degree, the prophetology of the philosophers. ${ }^{6}$

In his article on al-Ghazālì's concept of prophecy, Frank Griffel brings to light the influence of Avicenna (Ibn Sīna) on al-Ghazālī's doctrine of the proofs of prophecy. ${ }^{7}$ Although the early Ash'arite demonstration was exclusively based on miracles attributed to the one who claimed to be a prophet and testified through multiple traditions, later thinkers of the same school, namely al-Ghazālī (d. 505/1111) and Fakhr al-Dīn al-Rāzī (d. 606/1209), pointed out that the recourse to reported information presented many methodological problems. They showed that relying on traditions was inferior to the method they found in Avicenna's writings, which was based on inferring the existence of prophets from the proof of the existence of their effects, that is, the religion they established. ${ }^{8}$

The Andalusian philosopher Averroes (Ibn Rushd, d. 595/1198), a contemporary of al-Rāzī, took part in the discussion pertaining to the proof of prophecy with his book al-Kashf 'an manāhij al-adilla fi 'aqā'id al-milla [The exposition of the methods of proof concerning the beliefs of the community]. ${ }^{9}$ Averroes was very precise in dissecting the

6 Ibn Taymiyya, al-Nubuwwāt [Prophetology], 2 vols., ed. 'A. al-Ṭawiyān, (Riyadh: Maktabat Aḍwā' al-Salaf, 2000). To my knowledge, Ibn Taymiyya's proofs of prophecy have never been addressed in secondary literature until now.

7 F. Griffel, “Al-Ghazālī’s Concept of Prophecy: The Introduction of Avicennan Psychology into Ash arite Theology," Arabic Sciences and Philosophy 14 (2004), 101-144.

8 Fakhr al-Dīn al-Rāzī, al-Matălib al- 'āliya min al- 'ilm al-ilāhì [The higher issues of metaphysics], 8 vols., ed. A. Ḥ al-Saqqā (Beirut: Dār al-Kitāb al- 'Arabī, 1987), viii: 73-114. On Fakhr al-Dīn al-Rāzī's prophetology see also B. Abrahamov, "Religion versus Philosophy. The Case of Fakhr al-Dīn al-Rāzī’s Proofs of Prophecy," Oriente Moderno 3 (2000), 415-25.

9 Ibn Rushd, al-Kashf 'an manāhij al-adilla fì 'aq ā' id al-milla [The Exposition of the Methods of Proofs Concerning the Beliefs of the Community], ed. M. A. al-Jābirī (Beirut: Markaz Dirāsāt alWaḥda al-'Arabiyya, 1998), 175-185. 
arguments of those in favor of the miracle-based proof of prophecy (namely the ancient Ash'arī scholars). He pointed to the flaws of such arguments and charged them with being hasty when it came to validating the following syllogism:

1. He who claims to be a prophet has performed a miracle.

2. All those who perform a miracle are prophets.

Therefore, he who claims to be a prophet is a prophet.

Averroes developed an argument proving the validity of prophecy with a syllogism similar to al-Rāzī's and built as follows:

1. This man has the faculty to establish a religion.

2. All men who have the faculty of establishing a religion are prophets.

Therefore, this man is a prophet.

Averroes thus invalidates the early Ash'arite form of reasoning based on miracles, but he does it with a more radical statement than that offered by al-Rāzī, who simply considered it as less conclusive. According to the former, if miracles are convincing to the commoners (al- $\left.{ }^{c} \bar{a} m m a\right)$, they do not constitute, nonetheless, in any way, a proof. Averroes categorically states that miracles are not inherent to prophecy. In other words, miracles are no criterion from which to infer that a given man is a prophet. $^{10}$

"Whoever has the ability to establish a religion (wad $a l$-sharā’i) by revelation of the Lord, is a prophet (nabĩ). The fact that medicine has to do with healing, and that a physician is the one who heals, is well known in and of itself (ma lūm bi-nafsi-hi). In the same way: establishing a religion

10 See N. Zouggar, "La prophétologie d'Averroès dans le Kashf 'an manāhij al-adilla," Annales islamologiques 46 (2012), 387-408. 
by divine revelation is what prophets do and a prophet is whoever performs that deed."11

In his two aforementioned treatises (Dalā'il al-nubuwwa and al-Nubuwwāt), Ibn Taymiyya criticizes the proof of prophecy by way of miracles; he dismisses it and prefers al-Rāzì's and Averroes's demonstration.

Ibn Taymiyya's main argument against the method he ascribes to the Ash'arite school is that miracles are not specific to prophets since it has been proven that people other than prophets can also perform miracles. ${ }^{12}$

In reality, what proves (yadull 'alā) prophecy is a sign (āya) of prophecy and a demonstration of it (burhān). It must be specific to prophecy and not common between the prophets or others, because the proof (al-dalīl) has to be concomitant (mulāzim) to the proven object (al-madlūl), and its existence must not be more widespread than that of its object. Hence, the prophet's sign must not be found with others than the prophets . . . Furthermore, the fact that this sign breaks the usual course of things is a distinctive feature that is not found in the Qur’ān, nor in the Hadith nor with the salaf.13

According to Ibn Taymiyya, it is incorrect to consider miracles as usually defined by theologians, that is to say, phenomena breaking with the usual course of things, as evidence of prophecy. He mentions two reasons why miracles cannot be accepted as proper evidence. First, "What is considered as being miraculous, or not, has to do with

11 Averroes, al-Kashf, 180.

12 Ibn Taymiyya, Dalā'il al-nubuwwa, 363.

13 Ibn Taymiyya, al-Nubuwwāt, i: 163. 
what is relational (nisbī) and with what is relative (idāfí)." ${ }^{14}$ In this regard, Ibn Taymiyya argues that some are used to knowing or doing things that others may consider as breaking with what they know or do, for instance, physicians and scientists who observe rather unusual phenomena. ${ }^{15}$ Secondly, breaking with the usual course of things by performing miracles is a common phenomenon, shared not only by prophets, but also ordinary people such as magicians and soothsayers. Ibn Taymiyya adds to his argument that the prophet's wife Khadija bt. Khuwaylid and the prophet's companion and future caliph Abū Bakr al-Șiddiq, as well as others among the first Muslims, had all believed Muhammad's prophecy to be true long before "the moon be split" and before he revealed unknown things, and even before he started confronting people with the Qur’ān.16

Ibn Taymiyya gives examples of conversions of kings and renown people, whose stories show that they adhered to Islam only thanks to Muhammad's virtues. ${ }^{17}$

According to Ibn Taymiyya, the correct method for validating the existence of prophets is the same used for recognizing a certain type (jins) of human being that God has characterized with certain distinctive features: "You learn it through their discourses and actions, as is the case with physicians and jurists (al-ațibba' wa ' $l$ fuqahā')."18 Ibn Taymiyya adds that prophets' signs are obvious (yatabayyan) on earth and "he who has not seen their signs (āthāra-hum) in any given country only needs to travel around to see them and hear their recurrent stories."19

14 Ibn Taymiyya, al-Nubuwwāt, i: 164.

15 Ibn Taymiyya, al-Nubuwwāt, i: 174.

16 Ibn Taymiyya, Dalä'il al-nubuwwa, 375.

17 Ibn Taymiyya, Dalà'il al-nubuwwa, 376, 380.

18 Ibn Taymiyya, al-Nubuwwāt, i: 198.

19 Ibn Taymiyya, al-Nubuwwāt, i: 199. 
Ibn Taymiyya advocates for a demonstration through the "why" of prophecy (in

Arabic: burhān al-limā; in Latin: demonstratio propter quid) that consists in validating the prophet Muhammad's mission from the actual perception of the existence of the Islamic religion.

While studying this specific aspect of Ibn Taymiyya's discourse during my doctoral research, I concluded that Ibn Taymiyya was greatly influenced by Averroes's arguments, although one cannot disregard that al-Ghazālī and al-Rāzī could also very well have constituted other plausible sources for his thought on this subject. Numerous features of intertextuality led me to think that Averroes's Kashf is a primary source for Ibn Taymiyya's proof of prophecy. Indeed, besides comparing prophets and physicians, a comparison Averroes widely uses in his dissertation, Ibn Taymiyya insists on the need to demonstrate the existence of a type (al-jins) of human called a prophet as opposed to individual prophets, in step with what Averroes did. Finally, I would add that Ibn Taymiyya was familiar with Averroes's Kashf: his extensive quoting of passages from it in his $\operatorname{Dar}^{`} t^{`} a \bar{r} u d \underline{d}$ al-`aql wa-l-naql points to that.

Several common features between Averroes and Ibn Taymiyya have been revealed by recent studies..$^{20}$ It is especially in Ibn Rushd's dialectical writings, that is

20 See A. M. al-Ṣaghīr, "Mawāqif Rushdiyya li-Taqī al-Dīn Ibn Taymiyya? Mulāhazāât awwaliyya," [Did Ibn Taymiyya hold Rushdian opinions? Preliminary remarks] in Dirāsāt maghribiyya muhdāt ilā 'l-mufakkir al-maghribī Muhammad 'Aziz al-Habbābī, [Moroccan Studies Offered to the Moroccan Thinker Muhammad 'Azīz al-Habbābī ], $2^{\text {nd }}$ ed. (Rabat: al-Markaz al-thaqāfī al'arabī, 1987), 164-182. This is the first publication that highlighted the affinities and similarities between Ibn Rushd and Ibn Taymiyya. And A.-R. al-Tlīlin, "Āthār Ibn Rushd fî̀ '1-mashriq al'arabī. Ṭabī' at al-radd al-taymī 'alā falsafat Ibn Rushd," [Ibn Rushd's Heritage in the Mashrek. The Nature of Ibn Taymiyya's Refutation to Ibn Rushds Philosophy] in al-Mishkāt 3 (2005), 5570. This study addresses Ibn Taymiyya's critique of Ibn Rushd's Kashf and concludes by raising the hypothesis of a Rushdian influence on the former, but it unfortunately does not demonstrate it. See also J. Hoover, "Perpetual creativity in the perfection of God: Ibn Taymiyya's Hadith commentary on God's creation of this world," Journal of Islamic Studies 15.iii (2004), 287-329. A. Von Kügelgen, "The Poison of Philosphy: Ibn Taymiyya's Struggle for and against Reason," in Islamic Theology, Philosophy and Law: Debating Ibn Taymiyya and Ibn Qayyim al-Jawziyya, eds. B. Krawietz and G. Tamer (Berlin: de Gruyter, 2013), 253-328: 259-260. G. Tamer, "The 
the Kashf and Tahäfut al-Tahāfut [The Incoherence of the Incoherence], that Ibn Taymiyya has very likely drawn some epistemological answers to key theological problems. In this regard, Jon Hoover disclosed how Ibn Taymiyya adopted a view on God's perpetual creativity that is very similar to that of Ibn Rushd. ${ }^{21}$ Given that both authors shared the same intellectual adversaries, namely Avicenna and the Ash'arite theologians, especially al-Ghazālī, it is not surprising that Ibn Taymiyya borrowed from the Andalusian philosopher some of his compelling arguments.

\section{Ibn Qayyim al-Jawziyya (d. 751/1350)}

I would like to turn now to Ibn Taymiyya's closest disciple: Ibn Qayyim al-Jawziyya (691/1292-751/1350). The latter left a section dedicated to the proof of Muhammad's prophecy that occupies the last part of one of his early monographs, the Hidayat alhayāra fi ajwibat al-Yahūd wa-l-Nașāra [Guiding the Confused on Responses to the Jews and the Christians].22

This monograph is divided into two sections. The first tackles seven theoretical questions dealing with misrepresentations of Islam by Jews and Christians. The second takes up 5 percent of the book and is titled Fī taqrīr nubuwwat Muhammad bi-jamī anwā̄ al-dalā’il [Establishing Muhammad's Prophecy by All Kinds of Proofs].

Curse of Philosophy: Ibn Taymiyya as a Philosopher in Contemporary Islamic Thought," in Islamic Theology, eds. B. Krawietz and G. Tamer, (Berlin: de Gruyter, 2013), 329-374.

21 See Hoover, "Perpetual Creativity," 290-295.

22 Ibn Qayyim al-Jawziyya, Hidāyat al-hayāra fì ajwibat al-Yahūd wa-l-Nașāra, ed. M. A. al-Hājj (Damascus, 1996). For a more general account of Ibn Qayyim's life and bibliography, see B. Krawietz, "Ibn Qayyim al-Jawziyyah: His Life and Works," Mamlūk Studies Review 10/2 (2006) 19-64; L. Holtzman, "Ibn Qayyim al-Jawziyyah," in Essays in Arabic Literary Biography 13501850, eds. D. J. Stewart and J. E. Lowry (Wiesbaden: Harrassofitz Verlag, 2009), 202-223. On his life and work in general, see Bori-Holtzman's introduction to the monographic issue of Oriente Moderno 2010 dedicated to Ibn Qayyim al-Jawziyya. 
I have compared this section with the last one of Ibn Taymiyya's al-Jawāb al-

șahịh where, as mentioned above, Ibn Taymiyya attempts to prove prophecy within a similar interreligious polemical context. Unlike his master, Ibn Qayyim al-Jawziyya openly broke away from the traditionalists' model of dalä'il al-nubuwwa; in fact, the theme of miracles, which is the key topic of those treatises, is not at all raised in his argumentation. Rather, his main argument is based on the principle that refuting Muhammad's prophecy amounts to refuting all other prophecies. ${ }^{23}$

In another book, titled al-Șawa iq al-mursala, Ibn Qayyim al-Jawziyya addresses the topic of the proof of prophecy. ${ }^{24}$ The main objective of this theological work, which follows closely Ibn Taymiyya's opus magnum Dar' ta'ārud al-'aql wa-l-naql, is to invalidate rational approaches to revelation, while, at the same time, to defend his views on divine attributes. ${ }^{25}$ In this regard, the author does not give a detailed argument but somewhat criticizes the Ash'arī proof of prophecy by way of miracles. The following is included in the 61st aspect (wajh) out of the 241 aspects listed by Ibn Qayyim al-

23 Ibn Qayyim al-Jawziyya, Hidāyat al-hayāra, 577. The same argument is set forth by the Yemeni salafî scholar Muhammad al-Shawkānī (1173/1759-1250/1839) in his Irshād al-thiqāt ilā ittifāq al-sharā' 'i 'alā-l-tawhīd wa'l-ma 'äd wa'l-nubuwwāt [Guiding the Beliefs toward the Religions' Agreement on God's Unicity, Resurrection, and Prophecy] (Beirut: Dār al-Kutub al- 'Ilmiyya, 1984), 68.

24 Ibn Qayyim al-Jawziyya, al-Sawā iq al-Mursala 'alā 'l-Jahmiyya wa'l-Mu 'ättila [The Unleashed Thunderbolts against the Jahmiyya and the Mu 'attila], 4 vols., ed. 'Alī b. Muhammad al-Dakhīl Allāh, (Riyadh: Dār al-`Āṣima, 1408/1987-1988). See Y. Qadhi, "The Unleashed Thunderbolts of Ibn Qayyim al-Ğawziyya: An Introductory Essay," in A Scholar in the Shadow: Essays in the Legal and Theological Thought of Ibn Qayym al-Ğawziyya, C. Bori and L. Holzman (eds.), Oriente Moderno, n.s. 90/1 (2010), 129-143.

25 For many years I thought that the modern circulation of Ibn Taymiyya's Dar' ta 'ârud al- 'aql wa'll-naql had been limited before its first full publication by Muhammad Rashād Sālim between 1979 and 1980, since only a third of the work had been published in 1903 on the margins of the Minhāj al-sunna al-nabawiyya. Yet, given the close connection between the Sawa' iq and the Dar', and the abridgment of the former (Mukhtașar al-ṣawā 'iq al-mursala) by the Shāfi 'i scholar Muhammad ibn al-Mawșilī (d. in Tripoli in 774/1372), which was published as early as 1348/1929-30 (and reprinted in 1370/1950-1951, Cairo), it is worth investigating more deeply the impact of al-Sawā iq al-mursala and its Mukhtașar as indirect Taymiyyan legacies during the first half of the 20th century. On the connection between these two works, see Qadhi, "The Unleashed Thunderbolts." 
Jawziyya in order to refute the prevalence of reason on revelation in the case of a conflict between the two:

Similarly, the method [i.e. relying exclusively on miracles] they used to prove the existence of prophecy: in reality, they did not prove any prophecy with it, because they based it on breaking the usual course of things (kharq al- ${ }^{c} \bar{a} d a$ ), which is a common feature between prophets and ordinary people. They remained puzzled as to designate what distinguishes the prophets and found nothing that gives satisfaction and leads to certainty.

Besides, the prophecy they affirmed does not amount to an existent quality (wașf wujūdì), rather it lies on the Eternal Word's connection to the prophet (bal hiya ta'alluq al-khițāb al-azalī bi-l-nabī). Yet, connection, according to them, is a matter of nonexistence (amr 'adamī). Hence, according to them, prophecy amounts to a matter of nonexistence, since they stated that it does not amount to a positive attribute that is subsistent in the prophet ['s essence] (șifa thubūtiyya qā’ima bi'l-nabì). ${ }^{26}$

By devaluing the cogency of miracles, Ibn Qayyim follows his master's path. However, the ontological argument he develops here is his own. Even though its substance comes from the teachings of Ibn Taymiyya, the latter never drew such a radical conclusion in order to invalidate his adversaries' prophetology. ${ }^{27}$

26 Ibn Qayyim al-Jawziyya, al-Sawā iq, iii: 987.

27 Ibn Taymiyya tackles the question of the nature of prophecy in many of his writings. He discusses the opinions of the Mu'tazila and the falāsifa according to whom prophecy is an attribute which subsist within the prophet's essence (sifa qã 'ima bi-nafs al-nabī), then he considers the Ash arīs 
Moreover, Ibn al-Qayyim's writings show familiarity with the views of the philosophers, namely Avicenna and al-Fārābī, on the prophetic institution and the significance it holds in his master's discourse on prophecy. ${ }^{28}$ In his polemical book Ighāthat al-lahfān min mașā'id al-Shayțān (Rescuing the distressed from Satan's snares), for instance, Ibn al-Qayyim states that:

Prophecy, according to them [i.e., the philosophers], is an $\operatorname{art}\left(\operatorname{san}^{c} a\right.$ ) among the noblest, such as politics (al-siyāsa), it is even the political regime of the crowd; a regime that many of them reject pretending that philosophy is the prophecy of the elite and prophecy is the philosophy of the multitude. ${ }^{29}$

This consideration of Ibn Qayyim summarizes one of the main accusations in Ibn Taymiyya's polemics against the philosophers.

who taught that prophecy is not a positive attribute but something that relies on the fact that God has spoken to an accountable person (mukallaf); this makes that person a prophet. Ibn Taymiyya resolves the issue by saying that prophecy is the combination of both definitions: it is a positive attribute subsistent within a person added to the connection with the Divine Word. See for example al-Nubuwwāt, ii: 986-988; al-Safadiyya, 2 vols, ed. M. R. Sālim, $2^{\text {nd }}$ ed. (Cairo: Maktabat Ibn Taymiyya, 1976), i: 225-229.

28 Especially Avicenna's, which is summarized and referred to as the main doctrine of the falāsifa. See Ibn Qayyim al-Jawziyya, Ighäthat al-lahfān min mașā'id al-Shaytān [Rescuing the Distressed from Satan's Snares], 2 vols, ed. M. 'U. Shams, (Mecca: Dār 'Ālam al-Fawā'id, 2010), ii: 1025. Aspects of Ibn Taymiyya's critique of Avicenna's prophetology are expounded in Y. Michot, “A Mamlūk Theologian's Commentary on Avicenna's Risalā Adhawiyya. Being a Translation of a Part of the Dar' al-ta âruḍ of Ibn Taymiyya, with Introduction, Annotation and Appendices," Journal of Islamic Studies 14/2 (2003), 149-203 and 14/3 (2003), 309-363.

29 Ibn Qayyim al-Jawziyya, Ighäthat al-lahfān, ii: 1026. This theme can be found in Ibn Taymiyya's numerous invectives against the falāsifa, especially al-Fārābī (d. 339/950). See Ibn Taymiyya, alRadd 'alā-l-mantiqiyyīn [The refutation of the logicians], ed. 'A.-S al-Kutubī (Bombay: alMatba a l-Qayyima, 1949), 441-444. Among the secondary sources that address the subject, see Michot, "A Mamlūk Theologian's" and O. Anjum, Politics Law and Community: The Taymiyyan Moment (Cambridge: Cambridge University Press, 2012), 207-208. For a comparative approach to the falāsifa's discourse on prophecy, see H. A. Davidson, Alfarabi, Avicenna and Averroes on Intellect. Their cosmologies, Theories of the Active Intellect and Theories of the Human Intellect (New York, Oxford: Oxford University Press, 1992) and F. Rahman, Prophecy in Islam: Philosophy and Orthodoxy, (London: George Allen \& Unwin, 1958). 


\section{Ibn al-Wazīr (d. 840/1436)}

The prominent Yemeni scholar Muhammad b. Ibrahīm al-Wazīr (d. 840/1436) was born in the protectorate (hijra) of al-Zahrawayn into a family of Zaydi scholars. ${ }^{30}$ Early in his lifetime, he broke with the teachings of his milieu and adhered to the traditionalist Sunni dogma. Ibn al-Wazīr traveled to Mecca and to Tā'izz, the capital of the Sunni Rasulid kingdom, in order to study the science of Hadith. Then he came back to his homeland, where he spent the rest of his life writing and teaching while engaging continuous doctrinal conflicts with the Zaydis.

One of his main biographers, the Yemeni 18th- and 19th-century Sunni reformer Muhamamad al-Shawkānī (d. 1250/1839) is full of praise for Ibn al-Wazīr, whose work he compares, due to its originality, to that of Ibn Hazm and Ibn Taymiyya. ${ }^{31}$ Al-Shawkānī describes Ibn al-Wazīr as a Sunni traditionalist who, in the meanwhile, was a real mujtahid, that is to say, independent of any canonical school. ${ }^{32}$

While many scholars refer to Ibn al-Wazìr as an heir of Ibn Taymiyya, the only study which illustrates the intellectual continuum between the two is Jon Hoover's

30 Biographical and bibliographical information on this author are to be found in his disciple alShawkānī's biographical repertoire al-Badr al-țāli 'bi-mahāsin man ba 'd al-qarn al-sābi '[The Rising Moon on the Merits of Those who Came after the Seventh Century], 2 vols, (Cairo: Mațba at al-Sa'āda, 1929), ii: 81, 90-93. However, the most exhaustive account of his life and work was published by the Yemeni historian Ismā' 1 l al-Akwa' (d. 2008) in the introduction of Ibn al-Wazīr's major work al- 'Awāsim wa'l-qawāsim fì 'l-dhabb 'alā sunnat Abì l-Qāsim [Dodges and Crashes in Defeating Abī l-Qāsim's Tradition], 9 vols, $2^{\text {nd }}$ ed., ed. S. al-Arna' ūt (Beirut: Mu' assat al-Risāla, 1996), i: 9-81. In western scholarly literature, the best account of this author's life and works is in J. Hoover, "Withholding Judgment on Islamic Universalism: Ibn al-Wazīr (d. 840/1436) on the Duration and Purpose of Hell-fire," in Locating Hell in Islamic Traditions, ed. Ch. Lange (Leiden: Brill, 2016), 208-237.

31 al-Shawkānī, al-Badr, 91. On the intellectual filiation between a-Shawkānī and Ibn al-Wazīr see B. Haykel, Revival and Reform in Islam: The Legacy of Muhammad al-Shawkānī, (Cambridge: Cambridge University Press, 2003), 10, 41, 108.

32 To this effect, al-Shawkānī refers to an exchange that supposedly occurred between Ibn al-Wazīr and one of his teachers in Mecca: The teacher advised him to join the Shāfi 'ì or the Hanafī rite, which upset Ibn al-Wazīr, who allegedly replied that if he needed to conform to any rite, he would follow that of the Zaydīs. See al-Shawkānī, al-Badr, 90; Hoover, "Withholding" 215. 
recently released article addressing Ibn al-Wazīr's debt to the doctrine of Ibn Taymiyya and Ibn Qayyim al-Jawziyya on the duration of hellfire. ${ }^{33}$

How did Ibn al-Wazìr came to know Ibn Taymiyya's writings? This is not completely clear. Yet, we do know that the Sunni Rasulid kingdom (1229-1454) in the south of Yemen was very attractive to Sunni scholars, some of whom could have brought these writings to this part of the Muslim world. ${ }^{34}$ Besides, when we read the ijāza released in Tā'izz by his Hadith instructor, Nafîs al-Dīn al-'Alawī (d. 825/1422), it appears that Ibn al-Wazīr's line of succession in the field of Hadith transmission goes back directly to Ibn Taymiyya's disciple Shams al-Dīn al-Dhahabī (d. 1348/748) through Nafīs al-Dīn's father Burhān al-Dīn al-'Alawī (d. 752/1352). ${ }^{35}$ Similarly, Ibn al-Wazīr could also have met Ibn Taymiyya's corpus when he was studying in Mecca. Besides, it must be stressed that Ibn Taymiyya is also mentioned as having given an ijāza to Burhān al-Dīn al-'Alawī. ${ }^{36}$ This is certainly not enough to fully detail how Ibn al-Wazīr came to familiarize with Ibn Taymiyya's writings, but it reveals an important aspect of the intellectual context of this encounter.

33 Studies mentioning an influence of Ibn Taymiyya on Ibn al-Wazīr are J. Hoover, "Withholding"; J. Hoover, "Against Islamic Universalism: 'Alī al-Harbi's 1990 Attempt to Prove that Ibn Taymiyya and Ibn Qayyim al-Jawziyya Affirm the Eternity of Hell-Fire," in Islamic Theology, eds. B. Krawietz and G. Tamer, (Berlin: de Gruyter, 2013), 377-399: 380-382; S. Özervarli, "The Qur'annic Rational Theology of Ibn Taymiyya and His Criticism of the Mutakallimūn," in Ibn Taymiyya and His Times, eds. Y. Rapoport and Sh. Ahmed (Karachi: Oxford University Press, 2010), 78-100: 95. See also Kh. El Rouayheb, "From Ibn Hajar al-Haythamī (d. 1566) to Khayr al-Dīn al-Alūsī (d. 1899): Changing Views of Ibn Taymiyya among Non-Hanbalī Sunni Scholars," in Ibn Taymiyya and His Times, eds. Y. Rapoport-Sh. Ahmed, (Karachi: Oxford University Press, 2010), 296-318: 304.

34 Hoover, "Withholding", 215 and A. D. Knysh, Ibn 'Arabi in the Later Islamic Tradition: the Making of a Polemical Image in Medieval Islam (Albany: SUNY Press, 1999), 232-234.

35 See al-Akwa's introduction to Ibn al-Wazīr, al- 'Awāṣim min al-qawāsim, 28. I would like to thank my colleague Bilal Megnai for drawing my attention to this passage.

36 See, the online Repertory of Yemeni Scholars: Mu jam a 'lām al-Yaman, eds. A. al-Shamīrì et al.: www.al-aalam.com/personinfo.asp?pid $=5557$ [Last accessed 02 Jan. 2017]. 
Ibn al-Wazīr devoted an important part of his writings to the topic of prophecy, which is an aspect of his theological work that has never been addressed in a study, neither for itself nor for its debt to Ibn Taymiyya.

Ibn al-Wazīr's most exhaustive dissertation on the subject is expounded in his al-

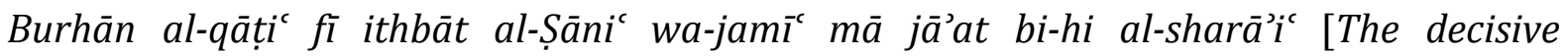
demonstration in affirming the Creator and all what religions conveyed]. ${ }^{37}$ Although its title suggests that the essay deals with the demonstration of the Creator's existence (ithbāt al-Ṣāni), this short treatise (94 pages in M. 'A. al-Khațîb's edition) is committed to the proof of prophecy and may be classified as part of the dalā'il al-nubuwwa genre.

As a late Hadith expert, Ibn al-Wazīr begins his dissertation with an advocacy for the compelling nature of knowledge obtained through several single-witness reports carrying the meaning of the same information yet in different narrations (al-tawātur al$\left.m a^{c} n a w \bar{i}\right)^{38}$ and insists on defending the epistemological value of single-witness reports (ahādith $\bar{a} h \bar{a} d$ ), which is the main source of information for most of the miracles ascribed to the prophet Muhammad. This section is very similar to the one Ibn Taymiyya develops in his Dalā'il al-nubuwwa in order to strengthen his argument. ${ }^{39}$

Ibn al-Wazīr leaves aside the classical method of listing Muḥammad's different types of miracles and enumerates instead eleven types of circumstantial evidence

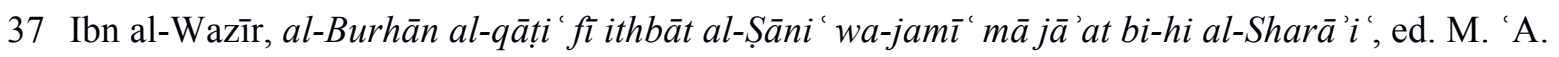
al-Khațīb (Damascus: Dār al-Ma'mūn lil-Turāth, 1988).

38 That is "tawātur with respect to meaning" which is distinct from the "verbatim tawätur" (altawātur al-lafzīi). The distinction was common between specialists of legal theory before alKhațīb al-Baghdādī (d. 463/1071) introduced it in the sciences of Hadith and spread it in the 13th century. For an overview of its use in the field of prophetology, see Ibn Taymiyya, Dalä'il alnubuwwa, 246. For an epistemological approach of this category of transmission, see W. Hallaq, "The Authenticity of Prophetic Hadith: A Pseudo-problem," Studia Islamica 99 (1999), 75-90.

39 See Ibn Taymiyya, Dalä 'il al-nubuwwa, 225-271. 
(qarä'in $)^{40}$ which are meant to prove the prophets' virtues and, more specifically, Muhammad's. According to Ibn al-Wazīr, decisive knowledge of the truthfulness of any prophet and the validity of Muhammad's prophetic mission can be deduced from the sum of these evidences. ${ }^{41}$

It is noteworthy that in this writing, Ibn al-Wazìr sets out to refute, in a Taymiyyan tone, the classification of knowledge as set by the logicians, arguing that it is not prohibited to affirm a necessary knowledge that is not considered as such by the logicians. ${ }^{42}$ By doing so, he addresses a hypothetical objector to the validity of his demonstration based on circumstantial evidence. ${ }^{43}$ Furthermore, as Ibn Taymiyya used to do, Ibn al-Wazìr refers to the speculative theologians to whom he associates the philosophers in a very systematic way, as his major adversaries.

Miracles and premonitions ascribed to prophets fall under the eighth kind of circumstantial evidence: Moses's miracle consists in morphing a stick into a snake; Jesus's miracle consists in healing the sick and raising the dead; whereas Muhammad came with a type of miracle "in which it is impossible to conceive magic (al-sihr) or mystification (al-ta'miya)." 44 With this type of miracle, the author means the Qur’ān.

According to him, the miraculous character of the Qur'ān lies in the fact that nobody could imitate or challenge it, not even talented experts like Wāṣil ibn 'Ațā (d.

40 Qara 'in in this context are indicators from the aggregation of which one can infer knowledge. For further details see W. Hallaq, "Notes on the term qarina in Islamic Legal discourse," Journal of the American Oriental Society, Vol. 108, 3(1988), 475-480.

41 Ibn al-Wazīr, al-Burhān, 42.

42 On Ibn Taymiyya's critique of logic, see R. Bruschwig, "Pour ou contre la logique grecque chez les théologiens juristes de l'islam: Ibn Hazm, al-Ghazālī, Ibn Taymiyya," in Etudes d'islamologie, 2 vols, (Paris: Maisonneuve et Larose, 1976), i: 303-327; W. Hallaq, Ibn Taymiyya Against The Greek Logicians. Translated with an Introduction and Notes (Oxford: Clarendon Press, 1993); A. Von Kügelgen, "The Poison of Philosophy"; Kh. al-Rouayheb, "Theology and Logic" in S. Schmitdke (ed.), The Oxford Handbook of Islamic Theology (Oxford: Oxford University Press, 2016), 408-435.

43 Ibn al-Wazīr, al-Burhān, 91.

44 Ibn al-Wazīr, al-Burhān, 36. 
131/748) or al-Jāḥiz (d. 255/868): “An evidence of the miraculous nature of the Qur’ān is that al-Jāḥiz believed in it (min dalā'̄il i jāz al-Qur'ān īmān al-Jāḥiẓ bi-hi)."45

Ibn al-Wazìr explains that every miracle sent to validate the truthfulness of a prophet is related to its historical context. Magicians were prevalent in Moses's time, which is why God sent a miracle that would convince them. As for Jesus, physicians were prevalent at the time so he came with a category of miracle that would convince them. In the time of Muhammad, it was eloquence that prevailed among the Arabs, so he brought a brilliant discourse that enthralled the very best of their rhetoricians and eloquent men. ${ }^{46}$

In a following chapter, Ibn al-Wazīr cites extensively a section of Fakhr al-Dīn alRāzì's Kitāb al-arba īn fì uṣūl al-dīn dedicated to the proof of Muhammad's prophecy, in order to support his views. ${ }^{47}$ In this book, al-Rāzī's demonstration was not yet echoing Avicenna's tenets. ${ }^{48}$ Nonetheless, in the $A r b a^{\text {ìn }}$ al-Rāzī does not dwell on miracles in their classical conception, namely as extraordinary occurrences that transcend what is expected or usual, but rather he dwells on what he calls "rational miracles" (al-mu jizizāt al-'aqliyya) such as the argument of incongruity between the qualities of the prophet and the weakness of his cultural milieu. According to al-Rāzī, the Arabs at the time of the prophet Muhammad could not have given rise to such a wise and learned man if God had not broken the usual course of things. ${ }^{49}$

45 Ibn al-Wazīr, al-Burhān, 38.

46 Ibn al-Wazīr, al-Burhān, 59.

47 Ibn al-Wazīr, al-Burhān, 43-50 and 63-75.

48 al-Rāzì's "Avicennan turn" in the field of prophetology is to be found in his ultimate work, alMațālib al- 'àliyya. See Abrahamov, "Religion," 417-422; and Griffel, "al-Ghazālī," 106-113.

49 al-Rāzī, al-Arba '̄in fì Ușūl al-Dìn, 2 vols, ed. A. Ḥ. al-Saqqā (Cairo: Maktabat al-Kulliyāt alAzhariyya, 1986), ii: 89-90. It is noteworthy that Averroes developed the same argument. See Averroes, al-Kashf, 18 and Zouggar, "La prophétologie d'Averroès," 401. 
Among the several discussions Ibn al-Wazīr develops in this book in order to demonstrate the validity of Muhammad's mission, the most personal one is related to the distinction made between prophetic miracles and magic. This well-developed argument is added by Ibn al-Wazīr in the middle of his al-Rāzī's excerpt. Its purpose is to prove that Muhammad could not by any chance have been a magician; its main argument is that if he had been a magician, he would have had to learn magic with some people, in which case those people would have spread the information in such a manner that there would not be any doubt left. ${ }^{50}$

Ibn al-Wazīr tackles the proof of prophecy much more briefly in two other books, namely Tarjīh asālīb al-Qur'ān 'alā asālīb al-Yūnān [The preponderance of the Qur'ānic methods over the methods of the Greeks] ${ }^{51}$ and İthär al-haqq 'alā-l-khalq fi radd alkhilāfät ilā-l-madhhab al-ḥaqq min ușūl al-tawhìd [Inciting human beings to the truth in turning the disagreements on the principles of unicity to the righteous doctrine]. ${ }^{52}$

Both books contain a section on prophecy that is almost identical to the previous one just described in al-Burhān. In particular, they mention a work Ibn Wazīr attributes to Ibn Taymiyya. This book bears the title al-Farq bayna al-ahwwāl al-rabbāniyya wa'lahwāl al-shaytāniyya [The Distinction between the Divine Condition and the Satanic Condition], which is obviously a warped one of al-Furqān bayna awliyāa al-Raḥmān waawliyā' al-Shayțān [The Distinction between the Allies of the Merciful and the Allies of Satan]. ${ }^{53}$ Ibn Taymiyya's contribution is mentioned by Ibn al-Wazīr among others that

50 Ibn al-Wazīr, al-Burhān, 50-63.

51 Ibn al-Wazīr, Tarjīh asālīb al-Qur'ān 'alā asālīb al-Yūnān (Beirut: Dār al-Kutub al- 'Ilmiyya, 1984).

52 Ibn al-Wazīr, İthār al-haqq 'alā-l-khalq fì radd al-khilāfāt ilā-l-madhhab al-haqq min ușūl altawhìd (Beirut: Dār al-Kutub al-'Ilmiyya, 1983).

53 Ibn Taymiyya, al-Furqān bayn awliyā' al-Raḥmān wa-awliyā' al-Shaytānn (Riyadh: Maktabat alMa'ārif, 1982). See Ibn al-Waz̄ir, Tarjīh, 108. Here the author qualifies Ibn Taymiyya's book as precious (wa-huwa kitāb nafìs); Ibn al-Waz̄īr, İthār, 68 . For a detailed overview on the content 
address the distinction between the miracles ascribed to the prophets and those which are performed by common people. This distinction being fundamental to Ibn Taymiyya in this book and elsewhere, it is very likely that Ibn al-Wazīr draw inspiration from it. ${ }^{54}$

Ibn Taymiyya does not mention Ibn Taymiyya further, nor does he textually draw from the latter, nevertheless, judging from the way Ibn al-Wazīr dealt with this issue, Ibn Taymiyya could have been very likely one of his sources of inspiration.

On the whole, Ibn al-Wazīr's position on this topic is rather peculiar. As a matter of fact, unlike Ibn Qayyim al-Jawziyya, Ibn al-Wazīr does not openly undermine miracles as proofs of prophecy. It is quite probable that he sought to preserve, at least in theory, the traditional methodology proper to the dalä'il al-nubuwwa genre. Indeed, to the question whether one can validate prophecy without recourse to miracles, Ibn al-Wazìr answers: "Reason does not require to prove prophecy by miracles but tradition (alsam ) does." By tradition, he means the consensus of the scholars (al-ijmāa) affirming that, "every prophet that God did not attest with a miracle is a liar." 55 But as we have seen, when it comes to defining Muhammad's miracles, he puts forward the Qur'ān and does not refer to the numerous other miracles raised by the traditionalists.

and scope of this work, see D. Sarrió Cucarella, "Spiritual Anti-Elitism: Ibn Taymiyya's Doctrine of Sainthood (walāya)," Islam and Christian-Muslim Relations 22/3 (2011), 275-291.

54 See Ibn Taymiyya, al-Furqān, 65-69, 71-75, 77-78. The distinction between prophetic miracles and other extraordinary deeds was a very important feature in the ancient Ash 'arite school, as evidenced by the Ash 'arī theologian al-Bāqillān̄̄'s (d. 403/1013) treatise Kitāb al-bayān 'an alfarq bayna al-mu 'jizāt wa'll-karāmāt wa'll-hiyal wa'l-kahāna wa'l-sihr wa'l-naranjāt [Miracle and Magic: A Treatise on the Nature of the Apologetic Miracle and its Differentiation from Charisms, Trickery, Divination, Magic and Spells], ed. and trans. R. J. McCarthy (Beirut: Librairie Orientale, 1958). Standing against the Ash arite views on this topic, Ibn Taymiyya has dedicated many pages to it in his al-Nubuwwāt. See for example, ii: 991-998, 1016-1030, 10741095.

55 Ibn al-Wazīr, al-Burhān, 81. 


\section{Conclusions}

With Ibn al-Wazīr's later heir and biographer, al-Shawkānī, who was also a reader of Ibn Taymiyya, the proof by way of miracles in the traditional sense came back to its rightful place. ${ }^{56}$ Ibn Taymiyya was certainly a polemicist who positioned himself as an advocate of the traditional sources of religious knowledge, but when it came to criticizing someone or something, he made an effort to study it, which at times led him to validate some of his adversaries' methods and conclusions.

Regarding Ibn Taymiyya's doctrine on the proofs of prophecy, this article drew attention to a direct influence of Averroes on Ibn Taymiyya, although we also met an indirect debt of Ibn Taymiyya to Avicenna when he validated the latter's views as recycled through al-Ghazālī and Fakhr al-Dīn al-Rāzì.

Moving to Ibn Qayyim al-Jawziyya, Ibn Taymiyya's reverberation on this most devoted and famous disciple of his could appear as self-evident, nonetheless it is worth been investigated. In fact, Ibn Qayyim al-Jawziyya does not only echo his master's views; sometimes he summarizes and reshapes them in a matured discourse, as is the case here with the proof of prophecy where no place is left to miracles except for his critique of their use by Ash'arites. Ibn Qayyim al-Jawziyya's discourse on the proofs of prophecy is a wonderful example of how he clarifies Ibn Taymiyya's views on a given topic by pursuing his own reasoning and drawing consequences that do not appear in his master's writings. ${ }^{57}$

Finally, Ibn al-Wazīr's proofs of prophecy are based on rational arguments, the long excerpt from Fakhr al-Dīn al-Rāzì proves this. Yet, at the same time he proclaims his attachment to the tradition of proving the existence of prophets by miracles,

56 al-Shawkānī, Irshād al-thiqāt, 57-69.

57 See Bori-Holtzman, A Scholar in the Shadow, 11-42. 
although in the end he mentions no other miracle than the Coran. This makes Ibn alWazīr's method close to Ibn Taymiyya's who dedicated long pages to listing and classifying miracles in a traditional way, following the traditionalists' dalä'il alnubuwwa pattern, to finally challenge the miracles' conclusiveness.

Uncovering Ibn al-Wazīr's reception of Ibn Taymiyya is a crucial operation in many respects. First, this Yemeni theologian is very little studied, whereas his legacy played an important role in the spread of Sunnism in Yemen from the 15th century onwards. Moreover, his work testifies to the spread of Ibn Taymiyya's teachings in the Arabian Peninsula a century after his death.

\section{BIBILIOGRAPHY}

\section{Primary sources:}

Fakhr al-Dīn al-Rāzī, al-Mațālib al-'Āliya min al-`Ilm al-Ilāhī, 8 vols, ed. A. Ḥ al-Saqqā. (Beirut: Dār al-kitāb al-'arabī, 1987).

- al-Arbaīn fì ușūl al-dīn, 2 vols, ed. A. Ḥ. al-Saqqā,. (Cairo: Maktabat al-Kulliyāt alAzhariyya, 1986)

Ibn Rushd, al-Kashf 'an Manāhij al-Adilla fí 'Aqā'id al-Milla [The Exposition of the Methods of Proof Concerning the Beliefs of the Community], ed. M. A. al-Jābiri (Beirut: Markaz Dirāsāt alWahda al-'Arabiyya, 1998).

M. al-Shawkānī, Irshād al-thiqāt ilā ittifāq al-sharā'ic 'alā 'I-tawhīd wa'l-ma'ād wa'lnubuwwāt, (Beirut: Dāt al-Kutub al-'Ilmiyya, 1984).

- al-Badr al-țālic bi-maḥ̄asin man ba'd al-qarn al-sābic, 2 vols. (Cairo: Maṭba'at alSa'āda, 1929).

Ibn al-Wazīr, al-'Awāsim wa'l-Qawāsim fì 'l-Dhabb 'alā Sunnat Abī Qāsim, 9 vols, ed. S. alArna'ūṭ, (2nd ed, Beirut: Mu’assat al-Risāla, 1996).

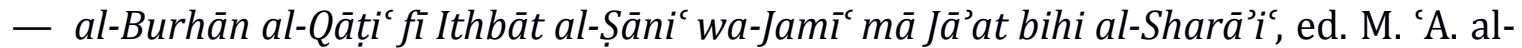
Khațīb (Damascus: Dār al-Ma'mūn li'l-Turāth, 1988).

- İthār al-Haqq 'alā 'l-Khalq fì Radd al-Khilāfāt ilā 'l-Madhhab al-Haqq min Ușūl al-Tawhị̀d (Beirut: Dār al-kutub al-'ilmiyya, 1983).

- Tarjīh Asālīb al-Qur’ān 'alā Asālib al-Yūnān (Beirut: Dār al-kutub al-'ilmiyya, 1984). 
Ibn Qayyim al-Jawziyya, Hidāyat al-Hayāra fi-ajwibat al-yahūd wa'l-nașāra, ed. M. A. alḤājj (Damascus: Dār al-Qalam, 1996).

- al-Șawā'iq al-Mursala 'alā 'I-Jahmiyya wa'l-Mu'āțțila, 4 vols., ed. 'Alī b. Muḥammad al-Dakhīl Allāh, (Riyadh: Dār al-`Āṣima, 1408/1987-1988).

- Ighāthat al-lahfān min mașāild al-Shayțān, 2 vols., ed. M. 'U. Shams, (Mecca: Dār 'Ālam al-Fawā'id, 2010).

Ibn Taymiyya, Dalā̉il al-Nubuwwa, Ḥ. b. M. al-Ḥamdān, (Riyadh: al-'Ubaykān, 2005).

- al-Jawāb al-Ṣahīh li-Man baddala Dīn al-Masīh, 7 vols, ed. 'A. b. Ḥ. al-Hamdān, (Riyadh: Dār al-'Āṣima, 1993-1999).

- al-Nubuwwāt, 2 vols., ed. 'A. al-Ṭawiyān, (Riyadh: Maktabat Aḍ̂̄’’ al-Salaf, 2000).

- al-Șafadiyya, 2 vols., ed. M. R. Sālim, $2^{\text {nd }}$ ed. (Cairo: Maktabat Ibn Taymiyya, 1976).

- al-Furqān bayn Awliyā’ al-Raḥmān wa-Awliyā’ al-Shayțān (Riyadh: Maktabat alMa'ārif, 1982).

\section{Secondary sources:}

B. Abrahamov, "Religion versus philosophy. The case of Fakhr al-Dīn al-Rāzī's proofs of Prophecy," Oriente Moderno 3 (2000), 415-25.

O. Anjum, Politics Law and Community: The Taymiyyan Moment (Cambridge: Cambridge University Press, 2012).

R. Bruschwig "Pour ou contre la logique grecque chez les théologiens juristes de l'Islam: Ibn Hazm, al-Ghazālī, Ibn Taymiyya" in Etudes d'islamologie, 2 vols. (Paris: Maisonneuve et Larose, 1976), i: 303-327.

H. A. Davidson, Alfarabi, Avicenna and Averroes on Intellect. Their cosmologies, Theories of the Active Intellect and theories of the Human Intellect (New York - Oxford: Oxford University Press, 1992).

Kh. El Rouayheb, "From Ibn Hajar al-Haythamī (d. 1566) to Khayr al-Dīn al-Alūsī (d. 1899): Changing views of Ibn Taymiyya among non-Hanbali Sunni scholars," in Ibn Taymiyya and His Times, eds. Y. Rapoport and Sh. Ahmed (Karachi: Oxford University Press, 2010), 269-318.

- "Theology and Logic" in S. Schmitdke (ed.), The Oxford Hanbook of Islamic Theology (Oxford: Oxford University Press, 2016), 408-435. 
F. Griffel, "Al-Ghazālī’s concept of Prophecy: The introduction of Avicennan Psychology into Ash'arite Theology”, Arabic Sciences and Philosophy 14 (2004), 101-144.

W. Hallaq, Ibn Taymiyya Against the Greek Logicians. Translated with an Introduction and Notes (Oxford: Clarendon Press, 1993)

- "The authenticity of Prophetic Hadith: A Pseudo-problem", Studia Islamica 99 (1999), 75-90.

- "Notes on the term qarīna in Islamic Legal discourse," Journal of the American Oriental Society, 108/3(1988), 475-480

B. Haykel, Revial and Reform in Islam: The Legacy of Muhammad al-Shawkānī, (Cambridge: Cambridge University Press, 2003).

L. Holtzman, "Ibn Qayyim al-Jawziyyah," in Essays in Arabic Literary Biography 13501850, D. J. Stewart and J. E. Lowry (eds.), (Wiesbaden: Harrassofitz Verlag, 2009), 202-223.

J. Hoover "Perpetual creativity in the perfection of God: Ibn Taymiyya's Hadith commentary on God's creation of this world," Journal of Islamic Studies 15/iii (2004), 287-329.

- "Withholding judgment on Islamic universalism: Ibn al-Wazì (d. 840/1436) on the duration and purpose of hell-fire," in Locating Hell in Islamic traditions. Islamic history and civilization, vol. 119 (Leiden: Brill, 2016), 208-237.

- “Against Islamic Universalism: 'Alī al-Harbī’s 1990 Attempt to Prove that Ibn Taymiyya and Ibn Qayyim al-Jawziyya Affirm the Eternity of Hell-Fire," in Islamic Theology, Philosophy and Law: Debating Ibn Taymiyya and Ibn Qayyim alJawziyya, eds. B. Krawietz and G. Tamer (Berlin: de Gruyter, 2013), 380-382.

A. D. Knysh, Ibn 'Arabi in the Later Islamic Tradition: the Making of a Polemical image in Mediaval Islam, Albany: SUNY Press, 1999.

B. Krawietz, "Ibn Qayyim al-Jawziyyah: His Life and Works," The Mamlūk Studies Review 10/2 (2006) 19-64.

Y. Michot, "A Mamlūk theologian's commentary on Avicenna's Risalā Adḥawiyya. Being a translation of a part of the Dar' al-ta'ârud of Ibn Taymiyya, with introduction, annotation and appendices," Journal of Islamic Studies 14/2 (2003), 149-203 and 14/3 (2003), 309-363. 
S. Özervarli, "The Qur’ānic Rational Theology of Ibn Taymiyya and His Criticism of the Mutakallimūn," in Ibn Taymiyya and His Times, eds. Y. Rapoport and Sh. Ahmed (Karachi: Oxford University Press, 2010), 78-100.

Y. Qadhi, "The unleashed Thunderbolts of Ibn Qayyim al-Ǧawziyya: An Introductory Essay," in A scholar in the Shadow: Essays in the Legal and Theological Thought of Ibn Qayym al-Ğawziyya, C. Bori and L. Holzman (eds.), Oriente Moderno n.s. 1 (2010), 129143.

F. Rahman, Prophecy in Islam: Philosophy and Orthodoxy, (London: George Allen \& Unwin, 1958).

A. M. al-Ṣaghīr "Mawāqif rushdiyya li-Taqī al-Dīn Ibn Taymiyya? Mulāhazāāt awwaliyya," Dirāsāt maghribiyya muhdāt ilā 'l-mufakkir al-maghribī Muḥammad 'Aziz al-Habbābī, 2nd ed. (Rabat, 1987), 164-182.

D. Sarrió Cucarella, "Spiritual Anti-Elitism: Ibn Taymiyya's Doctrine of Sainthood (walāya)," Islam and Christian-Muslim Relations 22.3 (2011), 275-291.

S. Stroumsa, Freethinkers of Medieval Islam, Ibn al-Rawandī, Abū Bakr al-Rāzī and their Impact on Islamic Thought (Leiden: Brill, 1999).

G. Tamer "The Curse of Philosophy: Ibn Taymiyya as a philosopher in contemporary Islamic thought," in Islamic Theology, Philosophy and Law: Debating Ibn Taymiyya and Ibn Qayyim al-Jawziyya, eds. B. Krawietz and G. Tamer (Berlin: de Gruyter, 2013), 329374.

A.-R. al-Tlīlī, "Āthār Ibn Rushd fî 'l-mashriq al-'arabī. Ṭabī'at al-radd al-taymī 'alā falsafat Ibn Rushd," Al-Mishkāt 3 (2005), 55-70.

A. Von Kügelgen "The Poison of Philosphy: Ibn Taymiyya's Struggle for and Against Reason," in Islamic Theology, Philosophy and Law: Debating Ibn Taymiyya and Ibn Qayyim al-Jawziyya, eds. B. Krawietz and G. Tamer (Berlin: de Gruyter, 2013), 253-328.

N. Zouggar, "La prophétologie d'Averroès dans le Kashf 'an manāhij al-adilla," Annales islamologiques 46 (2012), 387-408. 